\title{
Assessment of Water Quality Parameters in the Bikolo Watershed, Tana Basin, Ethiopia
}

\author{
Mariye Majo Shute ${ }^{1} \quad$ Teka Girmay Hishe $^{2 *} \quad$ Eusman Ebrahim Shumey $^{2} \quad$ Nigus Gabbiye Habtu $^{3}$ \\ 1.Lecturer, Department of Chemical Engineering, Technology Faculity, Debre Tabor University, Debre Tabor, \\ Ethiopia \\ 2.Lecturer, Department of Hydraulic and Water Resources Engineering, Technology Faculity, Debre Tabor \\ University, Debre Tabor, Ethiopia \\ 3.Associate Professor, Department of Chemical Engineering, Faculity of Chemical and Food Engineering, Bahir \\ Dar University, Bahir Dar Institute of Technology, Bahir Dar ,Ethiopia
}

\begin{abstract}
Horticulture is one of the thriving sectors in Ethiopia. However, it is also a risk for the environment due to the consumption of wide variety of chemicals and agricultural input that can affect different sources water quality. In addition to this Horticulture, use more water that can generate high amount of wastewater effluent. This study investigates the spatial and temporal variation of water quality along horticultural farm from Meshenti to Zegie Zuria watershed, Ethiopia. The effect of flower farm on ground and surface waters of tana watershed in Ethiopia was conducted during dry (January) and wet season (July) of 2017 based on physico-chemical and biological quality. 11 water quality parameters from six sampling points were measured and analyzed. The results showed that $\mathrm{GW}$ (pH range 5.30 to 6.81) was slightly acidic (low $\mathrm{pH}$ ) compared to $\mathrm{SW}$ (pH 7.32 to 10.67). GW turbidity ranged from 22.82 to $38 \mathrm{NTU}$ whereas that of SW ranged from 15.82 to $87.45 \mathrm{NTU}$ in both seasons. Chemical parameters measured in GW samples in this study were COD (ranging from 4.93 to $9.58 \mathrm{mg} / \mathrm{L}$ ) and BOD (1.35 to $4.20 \mathrm{mg} / \mathrm{L}$ ) whereas SW COD and BOD ranged from 91.45 to $129.33 \mathrm{mg} / \mathrm{L}$ and 3.52 to $27.53 \mathrm{mg} / \mathrm{L}$ respectively. TDS, DO, BOD, $\mathrm{NO}_{3}{ }^{-}$and $\mathrm{PO}_{4}{ }^{3-}$ showed significant difference $(\mathrm{p}<0.05)$ between the sampling points of spatial and temporal distribution of physico-chemical and biological.it can be conclude that the variations may come from the pollution of water quality by flower culture.
\end{abstract}

Keywords: Horticulture, Biological Oxygen Demand, chemical Oxygen Demand

DOI: $10.7176 / \mathrm{JEES} / 10-1-02$

Publication date: January $31^{\text {st }} 2020$

\section{INTRODUCTION}

Worldwide, agricultural water is used to grow fresh produce such as crops, flowers, roses, fruits, and vegetables as well as raising livestock for our diet. When there is increment in number of population, they need to invest indifferent sectors such as horticulture production to solve their problems, and this influences availability of water and its quality [1].The application of excessive fertilizers and pesticides in agricultural land particularly on areas which have high slope will affect different sources of water when it is washed by run off [2],([3] and this impact is higher when there is intense rainfall events. The reduction of water quality is directly proportional to rapid growth and changing of human life style.

Water quality is a subject of current debate and expresses the health of a water body according to the planned use. Many reports have detailed the significance of water quality in terms of aesthetics, drinking water, recreation and environmental quality. It is well known that changes in land use can result in changes in water quality due to nutrient and pollutant fluxes.

Agricultural land use includes land used for cultivating the soil, producing crops and raising livestock. Such land uses are a diffuse source of nitrogen and phosphorous to receiving water bodies. This is a problem because along with light, nitrogen and phosphorous limit growth of primary producers, with phosphorous being particularly limiting in freshwater ecosystems. Increases in these nutrients alter the growth and structure of these organisms. The loading of nutrients entering the river is important as high loads lead to eutrophication, increased production rates and a decline in water quality.

Horticulture has been adopted as an alternate in Ethiopia to obtain maximum income from agriculture to earn foreign exchange because the agro-climatic conditions of Ethiopia are appropriate for farming and the production of fruits, vegetables, and flowers here, naturally gifted topography, climate, and accessibility to European, Holland, Asian and Middle East markets has the potential to supply high-quality flowers, fruits, and vegetables to the world. The production of fruits and vegetable is increased in Ethiopia from time to time starting from 2000. According to the report FAO Ethiopia production fruit has increased from 1,018,000 to 1,249,336 metric ton and vegetable production has increased from 956,800 to $1,124,800$ metric ton[4].

The production of fruits and vegetable is increased in Ethiopia from time to time starting from 2000. According to the report FAO Ethiopia production fruit has increased from 1,018,000 to 1,249,336 metric ton and vegetable production has increased from 956,800 to $1,124,800$ metric ton. The National Bank of Ethiopia has 
reported that in 2000 and 2004 Ethiopia was exported horticulture products from 20,734 to 28,592 metric ton.

The rapidly increasing demand for flowers, fruits, and vegetables in developed countries has made them best exportable commodities. The flower sector has only recently become an important agricultural sector for Ethiopia when regarding the export potential. It is a relatively new but at the same time very dynamic sector. Since 2001 up to 2007 the export value of flowers has increased from US\$ 0.3 Million up to US\$ 113 Million be a focus for potential foreign investors of many regions [5].

Horticultural activities, especially those conducted intensively without any physical obstacle to chemical leaching into the environment, can cause a threat to the quality of this state's water resources. Concerns include over-watering, excessive or poorly timed use of fertilizers or pesticides, inappropriate storage of chemicals and disposal of wastes that can leach contaminants.

There are around 121 chemicals that enter the country for the floriculture industry which are found on the world health organization negative pesticide list, while environmentalists have characterized some of these chemicals as having carcinogenic potential, such hazardous chemicals are used in the flower farming sector in Ethiopia.

Agricultural activities are a source of nutrients to both freshwater and marine ecosystems [6]the concentrations of which have been strongly correlated to the percentage of agricultural land in its catchment [7].Pesticide and fertilizer runoff are examples of diffuse nutrient sources from agricultural land use [8].Horticultural intensification has had great impacts upon the water quality of receiving water bodies [9]. As a result, many studies have tried to understand the controls on nutrients from such activities entering water stores.

Floriculture, or flower farming, is a discipline of horticulture concerned with the cultivation of flowering and ornamental plants for gardens and for floristry, comprising the floral industry.

\section{MATERIALS AND METHODS}

\subsection{Description of the Study Area}

This study was conducted on the floriculture industry and the surrounding watershed from Meshenti to Zegie zuria where the industries are located, in Bahir Dar town. Meshenti which covers a total area of 425 hectares is located about 16kms from Bahir Dar town, Ethiopia on the road to Addis Ababa. The site was selected for horticulture site by the regional administration, considering its agro-climatic feature to the targeted project and its respective socioeconomic to the country. The climate of Meshenti is seasonal; winter (dry) months are hot and summer (rainy) months are cold.

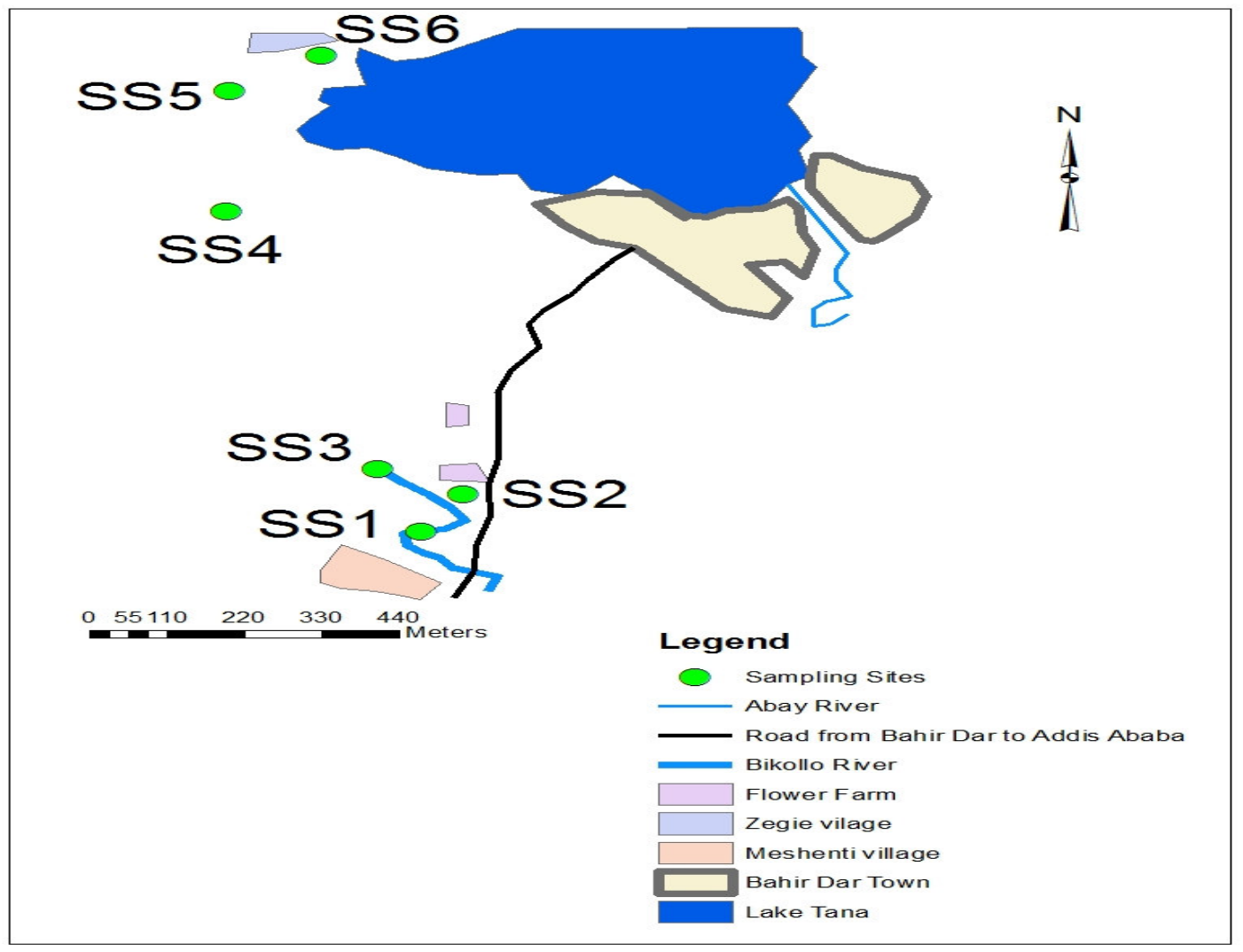

Figure 2-1 Location Map of the Study Area 
Table 2-1 GPS Coordinate of each sampling site

\begin{tabular}{|c|c|c|c|c|c|c|c|}
\hline \multirow[t]{2}{*}{ Site } & \multirow[t]{2}{*}{ Location } & \multicolumn{3}{|l|}{ Type of water sources } & \multirow{2}{*}{$\begin{array}{l}\text { Latitude } \\
\text { (North) }\end{array}$} & \multirow{2}{*}{$\begin{array}{l}\text { Longitude } \\
\text { (East) }\end{array}$} & \multirow{2}{*}{$\begin{array}{l}\text { Elevation } \\
(\mathrm{m})\end{array}$} \\
\hline & & Groundwater & Surface wate & & & & \\
\hline $\mathrm{SS}_{1}$ & \multirow{3}{*}{ Meshenti } & \multirow{3}{*}{$\begin{array}{l}\text { Boreholes with the help } \\
\text { of rope }(\mathrm{BH})\end{array}$} & \multirow{3}{*}{$\begin{array}{l}\text { Bikollo } \\
\text { (inflow to } \\
\text { Tana) }\end{array}$} & \multirow{3}{*}{$\begin{array}{r}\text { River } \\
\text { Lake }\end{array}$} & $11^{\circ} 30^{\prime} 05.09^{\prime \prime}$ & $37^{\circ} 17^{\prime} 35.19^{\prime \prime}$ & 1953 \\
\hline $\mathrm{SS}_{2}$ & & & & & $11^{\circ} 30^{\prime} 21.55^{\prime \prime}$ & $37^{\circ} 17^{\prime} 21.39^{\prime \prime}$ & 1931 \\
\hline $\mathrm{SS}_{3}$ & & & & & $11^{\circ} 30^{\prime} 49.16^{\prime \prime}$ & $37^{\circ} 17^{\prime} 10.37^{\prime \prime}$ & 1919 \\
\hline $\mathrm{SS}_{4}$ & \multirow{3}{*}{ Zegie } & \multirow{3}{*}{$\begin{array}{l}\text { Boreholes with the help } \\
\text { of rope }(\mathrm{BH})\end{array}$} & \multirow{3}{*}{$\begin{array}{l}\text { Bikollo } \\
\text { (inflow } \\
\text { Tana) }\end{array}$} & \multirow{3}{*}{$\begin{array}{l}\text { River } \\
\text { Lake }\end{array}$} & $11^{\circ} 30^{\prime} 01.17^{\prime \prime}$ & $37^{\circ} 18^{\prime} 52.54^{\prime \prime}$ & 1955 \\
\hline $\mathrm{SS}_{5}$ & & & & & 11'30'12.87' & $37^{\circ} 18^{\prime} 54.07^{\prime \prime}$ & 1969 \\
\hline $\mathrm{SS}_{6}$ & & & & & $11^{\circ} 30^{\prime} 43.64^{\prime \prime}$ & $37^{\circ} 18^{\prime} 37.67^{\prime \prime}$ & 1945 \\
\hline
\end{tabular}

\subsection{Sampling and Laboratory analysis}

During assessment of water quality in the Bikolo watershed, Tana basin concentration, eleven Physico-chemical and biological water quality parameters were analyzed from six sampling points in January and July 2017. Based on the site survey, a total of eleven water samples were collected from six sampling points along the greenhouses and watershed to assess the physicochemical, microbial and nutrients profile of the water. To observe the impact of the farm effluent on the water quality, samples were taken at six sampling sites such $\mathrm{SS}_{1}, \mathrm{SS}_{2}, \mathrm{SS}_{3}, \mathrm{SS}_{4}, \mathrm{SS}_{5}$ and $\mathrm{SS}_{6}$. Water samples were collected from Meshenti zuria Yinesa Sositu( Gogota, Achabir and Yinesa) and Zegie Zuria from six sampling points distributed alongside the flower farm using open water grab sampler $3 \mathrm{~L}$ capacity prepared with a simple pull - ring that allowed for sampling at various water depths of borehole (20 -27m deep) for groundwater samples. The sampling sites were located by using ArcGIS 10.1 (Geographic Information System) and accurately marked on the map to indicate the spatial variations by using GPS coordinates (Figure 2-1). The collected samples were kept in 1L polyethylene plastic bottles cleaned with metal-free soap, rinsed with de-ionized water and finally soaked in $10 \%$ nitric acid for $24 \mathrm{hr}$, finally rinsed with ultrapure water. All water samples were kept in an isolated cooler containing ice and delivered on the same to the laboratory and all samples were placed at a constant temperature $4^{\circ} \mathrm{C}$ to avoid any contamination and the effects of light and temperature investigation [10]

\section{Instruments and Equipment}

The instruments used for this study are; multi parameter water quality checker (model: YSI pro 30) used to check sample water quality such as Temperature, DO, $\mathrm{pH}$, TDS and turbidity once a time. Spectrophotometer (model: $\mathrm{P} / \mathrm{N}$ 4930060) was used to measure nitrate and phosphate content present in the samples. Digital portable $\mathrm{pH}$ meter (model: Bante 901 - UK) was used for measuring of $\mathrm{pH}$ of the water sample. Turbid meter (model: TN100) was also used to suspended and colloidal particles measurement present in the sample.

\subsection{Data Analysis}

In the experimental study, the samples were taken from two factors (ground and surface water) at six sampling stations (SS1, SS2, SS3, SS4, SS5, and SS6) and three replications have made for each sample. To analyze this data Microsoft Excel (Microsoft Office 2007) and SPSS ANOVA software (Version 20) was used for the statistical data analysis.

\section{RESULTS AND DISCUSSION}

The physico- chemical analysis test analysis was conducted in Blue Nile water institute laboratory, water development bureau office water quality laboratory, Amhara Design and Supervision Works Enterprise water quality in Bahir Dar town, Ethiopia. 
3.1 Spatial and temporal variation of groundwater Quality

Table 3-1 physical characteristics groundwater quality

\begin{tabular}{|c|c|c|c|c|c|c|}
\hline \multirow[t]{2}{*}{$\begin{array}{c}\text { Sampling } \\
\text { Sites }\end{array}$} & \multicolumn{2}{|c|}{$\mathrm{pH}$} & \multicolumn{2}{|c|}{ Turbidity (NTU) } & \multicolumn{2}{|c|}{$\begin{array}{c}\text { Temperature } \\
\left({ }^{\circ} \mathrm{C}\right)\end{array}$} \\
\hline & Dry season & $\begin{array}{c}\text { Wet } \\
\text { season }\end{array}$ & $\begin{array}{c}\text { Dry } \\
\text { Season }\end{array}$ & $\begin{array}{c}\text { Wet } \\
\text { Season }\end{array}$ & $\begin{array}{c}\text { Dry } \\
\text { season }\end{array}$ & $\begin{array}{c}\text { Wet } \\
\text { season }\end{array}$ \\
\hline \multirow{2}{*}{$\mathrm{SS}_{1}$} & 6.54 & 5.53 & 22.82 & 24.4 & 31.45 & 28.21 \\
\hline & \pm 0.16 & \pm 0.14 & \pm 3.51 & \pm 5.52 & \pm 1.24 & \pm 0.95 \\
\hline \multirow{2}{*}{$\mathrm{SS}_{2}$} & 5.71 & 5.45 & 25.64 & 25.78 & 32.14 & 28 \\
\hline & \pm 0.24 & \pm 0.12 & \pm 11.40 & \pm 13.61 & \pm 0.12 & \pm 0.51 \\
\hline \multirow{2}{*}{$\mathrm{SS}_{3}$} & 6.37 & 6.11 & 26.77 & 27.53 & 36.23 & 28.63 \\
\hline & \pm 0.21 & \pm 0.19 & \pm 2.32 & \pm 7.25 & \pm 7.12 & \pm 2.05 \\
\hline \multirow{2}{*}{$\mathrm{SS}_{4}$} & 5.68 & 6.22 & 29.31 & 33.69 & 32.54 & 29.43 \\
\hline & \pm 0.32 & \pm 0.17 & \pm 14.63 & \pm 12.77 & \pm 0.18 & \pm 3.17 \\
\hline \multirow{2}{*}{$\mathrm{SS}_{5}$} & 5.7 & 5.3 & 31.65 & 36.61 & 33.31 & 27.87 \\
\hline & \pm 0.31 & \pm 0.30 & \pm 10.91 & \pm 18.44 & \pm 1.20 & \pm 1.02 \\
\hline \multirow{2}{*}{$\mathrm{SS}_{6}$} & 6.81 & 6.35 & 32.05 & 38.32 & 32.91 & 28.62 \\
\hline & \pm 0.20 & \pm 0.11 & \pm 6.74 & \pm 16.11 & \pm 0.94 & \pm 1.32 \\
\hline
\end{tabular}

pH

The $\mathrm{pH}$ results for the water samples was ranged from 5.30 to 6.81 during dry season and from 5.30 to 6.35 during wet season, which was within the WHO allowable limit of $5.5-7.5$ for drinking water. The $\mathrm{pH}$ values within the range of 5.5 - 7.5 were suitable for the normal range of irrigation[4]. The $\mathrm{pH}$ of the Groundwater falls within FAO and WHO water quality guidelines for irrigation and drinking purposes.

\section{Turbidity}

Turbidity from table 3-1 above, maximum turbidity was recorded as 38.32 NTU during wet season and whereas 32.05 NTU in the dry season. During rainy season different dissolved particle such as silt, clay and other suspended particles contribute to the higher turbidity. The observed values of turbidity were above the WHO guide limit for both seasons in the study area.

\section{Temperature}

The temperature of water samples analyzed was a mean temperature value for all locations during the dry season (Table 3-1) was $33.09 \pm 8.12^{\circ} \mathrm{C}$, and the mean temperature during the wet season (Table 3-1) was $28.46 \pm 4.91^{\circ} \mathrm{C}$. The values were within WHO standard for drinking and domestic purposes of temperature not exceeding $30-40 \mathrm{oC}$ [11].

Table 3-2 chemical characteristics of groundwater quality

\begin{tabular}{lllllllll}
\hline \multirow{2}{*}{$\begin{array}{l}\text { Samp } \\
\text { ling sites }\end{array}$} & \multicolumn{2}{c}{$\mathrm{TH}(\mathrm{mg} / \mathrm{L})$} & \multicolumn{2}{c}{ BOD $(\mathrm{mg} / \mathrm{L})$} & \multicolumn{2}{c}{ COD $(\mathrm{mg} / \mathrm{L})$} & \multicolumn{2}{c}{ TDS (mg/L) } \\
\cline { 2 - 9 } & $\begin{array}{c}\text { Dry } \\
\text { Season }\end{array}$ & $\begin{array}{c}\text { Wet } \\
\text { Season }\end{array}$ & $\begin{array}{c}\text { Dry } \\
\text { season }\end{array}$ & $\begin{array}{c}\text { Wet } \\
\text { Season }\end{array}$ & Dry season & Wet season & Dry season & $\begin{array}{c}\text { Wet } \\
\text { Season }\end{array}$ \\
\hline $\mathrm{SS}_{1}$ & 112.63 & 147.15 & 1.51 & 1.35 & 6.88 & 5.07 & 395.41 & 472.72 \\
& \pm 3.04 & \pm 5.12 & \pm 1.13 & \pm 1.43 & \pm 0.48 & \pm 0.14 & \pm 8.45 & \pm 123.34 \\
$\mathrm{SS}_{2}$ & 124.75 & 195.45 & 2.49 & 1.53 & 7.19 & 6.55 & 458.22 & 499.85 \\
& \pm 5.37 & \pm 7.96 & \pm 1.08 & \pm 1.31 & \pm 0.22 & \pm 0.23 & \pm 72.32 & \pm 121.25 \\
$\mathrm{SS}_{3}$ & 190.55 & 247.86 & 2.58 & 2.32 & 9.58 & 4.93 & 476.45 & 520.36 \\
& \pm 7.11 & \pm 12.43 & \pm 2.63 & \pm 3.64 & \pm 0.92 & \pm 0.35 & \pm 143.51 & \pm 14.53 \\
$\mathrm{SS}_{4}$ & 265.84 & 285.93 & 2.68 & 2.51 & 7.38 & 5.44 & 489.32 & 541.53 \\
& \pm 8.16 & \pm 10.05 & \pm 5.45 & \pm 4.23 & \pm 0.31 & \pm 0.40 & \pm 162.40 & \pm 123.67 \\
$\mathrm{SS}_{5}$ & 287.34 & 310.12 & 3.7 & 2.95 & 7.39 & 7.04 & 497.37 & 574.35 \\
& \pm 2.82 & \pm 3.75 & \pm 6.32 & \pm 7.47 & \pm 0.50 & \pm 0.54 & \pm 12.21 & \pm 132.56 \\
$\mathrm{SS}_{6}$ & 296.85 & 332.35 & 4.2 & 3.45 & 8.67 & 4.94 & 502.3 & 583.21 \\
& \pm 1.93 & \pm 4.88 & \pm 8.31 & \pm 11.16 & \pm 1.34 & \pm 0.29 & \pm 23.66 & \pm 145.23 \\
\hline
\end{tabular}

\section{Total hardness}

In study areas, total hardness $(\mathrm{TH})$ values ranged from $112.63 \pm 3.04 \mathrm{mg} / \mathrm{L}$ to $296.85 \pm 1.93 \mathrm{mg} / \mathrm{L}$ during the dry season and from $147.15 \pm 5.12 \mathrm{mg} / \mathrm{L}$ to $332.35 \pm 4.88 \mathrm{mg} / \mathrm{L}$ in wet season (Table 3-2), respectively. Total hardens content in al study areas was within the World Health Organization (WHO) hardness of water should be $500 \mathrm{mg} / \mathrm{L}$ for potable water, irrigation, agriculture and domestic uses.

BOD

The minimum value of BOD for the dry season was $1.51 \pm 1 \mathrm{mg} / \mathrm{Land}$ that of rainy season was $1.35 \pm 1.43 \mathrm{mg} / \mathrm{L}$. Those values were above the permissible level of WHO drinking water standards of above $5 \mathrm{mg} / \mathrm{L}$. 


\section{COD}

As shown in table 3-2, the mean COD content during dry season was $7.84 \pm 0.33 \mathrm{mg} / \mathrm{L}$ and then at of rainy season $5.66 \pm 0.16 \mathrm{mg} / \mathrm{L}$. There was no WHO/EPA recommended value for COD for agriculture, aquatic life and domestic uses for groundwater.

\section{Total Dissolved Solids (TDS)}

The total dissolved solids (TDS) shows the degree of dissolved substances such as metal ions in the water. From the above table 3-2 the maximum value of TDS was $502.30 \mathrm{mg} / \mathrm{L}$ at dry season and $502.30 \mathrm{mg} / \mathrm{L}$ at the rainy season. The mean values of TDS for wet seasons were above the WHO permissible value while dry seasons are below the limit.

Table 3-3 nutrient characteristics of groundwater quality

\begin{tabular}{llccc}
\hline Sampling sites & \multicolumn{2}{c}{$\mathrm{NO}_{3}{ }^{-}(\mathrm{mg} / \mathrm{L})$} & $\mathrm{PO}_{4}{ }^{3-}(\mathrm{mg} / \mathrm{L})$ \\
\cline { 2 - 5 } & Dry season & Wet season & Dry season & Wet season \\
\hline $\mathrm{SS}_{1}$ & $39.41 \pm 11.03$ & $51.87 \pm 20.21$ & $0.52 \pm 0.05$ & $0.77 \pm 0.02$ \\
$\mathrm{SS}_{2}$ & $40.23 \pm 7.05$ & $53.75 \pm 15.62$ & $0.85 \pm 0.03$ & $0.82 \pm 0.07$ \\
$\mathrm{SS}_{3}$ & $45.12 \pm 9.21$ & $70.63 \pm 22.03$ & $1.24 \pm 0.06$ & $0.91 \pm 0.09$ \\
$\mathrm{SS}_{4}$ & $61.70 \pm 13.45$ & $52.40 \pm 8.14$ & $1.78 \pm 0.01$ & $1.20 \pm 0.08$ \\
$\mathrm{SS}_{5}$ & $57.64 \pm 21.74$ & $65.11 \pm 33.44$ & $1.50 \pm 0.04$ & $1.93 \pm 0.05$ \\
$\mathrm{SS}_{6}$ & $68.51 \pm 19.06$ & $88.53 \pm 42.32$ & $1.36 \pm 0.02$ & $2.50 \pm 0.03$ \\
\hline
\end{tabular}

The $\mathrm{NO}_{3}{ }^{-}$concentrations in all the six sampling points in wet seasons and sampling points $\mathrm{SS}_{4}, \mathrm{SS}_{5}$ and $\mathrm{SS}_{6}$ in dry seasons were above the acceptable WHO guideline value of $50 \mathrm{mg} / \mathrm{L}$. Therefore, water from these study area was used for other domestic purposes such as for washing than drinking.

\section{Phosphates}

The concentration of phosphate in the water sampled from the sampling points ranged from $0.52 \pm 0.05$ to $1.78 \pm$ $0.01 \mathrm{mg} / \mathrm{L}$ in the dry season and $0.77 \pm 0.02$ to $2.50 \pm 0.03 \mathrm{mg} / \mathrm{L}$ in the rainy season (Table 3-3). The higher levels were observed in boreholes during the wet season in all sampling points and the least level was observed in dry Seasons. The concentration of $\mathrm{PO}_{4}{ }^{3-}$ both in the dry and wet seasons in all sampling sites were above FEPA provisional standards $\left(\mathrm{PO}_{4}{ }^{3-}=0.005 \mathrm{mg} / \mathrm{L}\right)$. All the six sampling sites show that water in the study area exceeded WHO maximum allowable limit of $0.1 \mathrm{mg} / \mathrm{L}$.

\subsection{Spatial and Temporal Changes in Physicochemical Parameters in Surface Water}

The results of the spatial and temporal variation in surface water physical parameters measured at all the six sampling sites over the study period are presented in table 3-4 below.

Table 3-4 physical characteristics of surface water quality

\begin{tabular}{ccccccc}
\hline \multirow{2}{*}{$\begin{array}{c}\text { Sampling } \\
\text { sites }\end{array}$} & \multicolumn{2}{c}{$\mathrm{pH}$} & \multicolumn{2}{c}{ Turbidity(NTU) } & \multicolumn{2}{c}{ Temperature $\left({ }^{\circ} \mathrm{C}\right)$} \\
\cline { 2 - 7 } & Dry season & $\begin{array}{c}\text { Wet } \\
\text { season }\end{array}$ & Dry season & $\begin{array}{c}\text { Wet } \\
\text { season }\end{array}$ & $\begin{array}{c}\text { Dry } \\
\text { season }\end{array}$ & $\begin{array}{c}\text { Wet } \\
\text { season }\end{array}$ \\
\hline \multirow{2}{*}{$\mathrm{SS}_{1}$} & 7.32 & 8.79 & 15.82 & 17.28 & 19.55 & 17.51 \\
& \pm 0.30 & \pm 0.47 & \pm 14.30 & \pm 13.34 & \pm 8.13 & \pm 9.23 \\
$\mathrm{SS}_{2}$ & 9.65 & 10.67 & 20.54 & 34.78 & 20.53 & 19.58 \\
& \pm 0.50 & \pm 0.52 & \pm 17.19 & \pm 21.12 & \pm 7.86 & \pm 5.75 \\
$\mathrm{SS}_{3}$ & 8.28 & 9.94 & 17.87 & 55.43 & 21.81 & 20.94 \\
& \pm 0.23 & \pm 0.31 & \pm 11.32 & \pm 34.04 & \pm 9.13 & \pm 10.12 \\
$\mathrm{SS}_{4}$ & 7.74 & 10.17 & 19.51 & 65.19 & 19.06 & 18.58 \\
& \pm 0.35 & \pm 0.64 & \pm 16.14 & \pm 45.06 & \pm 8.10 & \pm 7.71 \\
$\mathrm{SS}_{5}$ & 7.75 & 8.3 & 21.55 & 71.31 & 19.31 & 18.87 \\
& \pm 0.44 & \pm 0.86 & \pm 19.20 & \pm 38.31 & \pm 6.45 & \pm 4.83 \\
$\mathrm{SS}_{6}$ & 8.21 & 9.35 & 18.67 & 87.45 & 20.11 & 19.62 \\
\end{tabular}

pH

The observation of $\mathrm{pH}$ in surface water, sampling sites-2 $\left(\mathrm{SS}_{2}\right)$ and $\mathrm{SS}_{4}$ had highest $\mathrm{pH}(10.67 \pm 0.52)$ and $(10.17 \pm 0.64)$ respectively during wet season among all the study sites and the lowest $\mathrm{pH}(8.30 \pm 0.86)$ was found at site-5 $\left(\mathrm{SS}_{5}\right)$. The $\mathrm{pH}$ values in dry season fluctuated from $7.32 \pm 0.30$ to $9.65 \pm 0.50$, whereas it varied from 8.30 \pm 0.86 to $10.67 \pm 0.52$ in the wet season. A range of $6.5-8.5$ is suggested by WHO for surface water for drinking, domestic and agricultural purposes. The measured results at $\mathrm{SS}_{1}, \mathrm{SS}_{3}, \mathrm{SS}_{4}, \mathrm{SS}_{5}$ and $\mathrm{SS}_{6}$ during the dry season and $\mathrm{SS}_{5}$ in wet season were within the WHO guideline limit value for drinking, domestic, fishery and agricultural purposes. $\mathrm{SS}_{2}$ in the dry season and except $\mathrm{SS}_{5}$ all measured values in wet seasons were above WHO guideline value. 


\section{Turbidity}

Turbidity in Lake Tana nearby Zegie recorded ranges between $15.82 \pm 14.30 \mathrm{NTU}$ to $87.45 \pm 62.43 \mathrm{NTU}$ during the wet season. The maximum turbidity in water was recorded during wet season at $\mathrm{SS}_{6}(87.45 \pm 62.43 \mathrm{NTU})$. Turbidity in the studied area was within WHO guideline values of 5 - 25 NTU during the dryseason.

\section{TDS}

From the data recorded table 3-4 the maximum total dissolved solids were observed during the wet season at the sampling site, $\mathrm{SS}_{4}(633.33 \pm 321.21 \mathrm{mg} / \mathrm{L})$ than the dry season at sampling site, $\mathrm{SS}_{5}(565.45 \pm 120.91 \mathrm{mg} / \mathrm{L})$. Almost all samples were observed within the limits $500-1500 \mathrm{mg} / \mathrm{L}$ of WHO for drinking purpose, aquatic life and irrigation.

\section{Temperature}

The measured temperature of water sample ranges between $19.06 \pm 8.10$ to $21.81 \pm 9.13^{\circ} \mathrm{C}$ during the dry season, whereas it varied between the ranges of $17.51 \pm 9.23$ to $20.94 \pm 10.12^{\circ} \mathrm{C}$ during the rainy season. All water samples in this study had temperature values in the acceptable limit of $\mathrm{WHO}$ guidelines (less than $12-25^{\circ} \mathrm{C}$ ) for drinking, aquatic life, bathing, and irrigation purpose for surface water.

Table 3-5 chemical characteristics of surface water quality

\begin{tabular}{l|llllllllll}
\hline \multirow{2}{*}{$\begin{array}{l}\text { Samplin } \\
\text { g sites }\end{array}$} & \multicolumn{2}{l}{ DO $(\mathrm{mg} / \mathrm{L})$} & \multicolumn{2}{l}{ TH $(\mathrm{mg} / \mathrm{L})$} & \multicolumn{2}{l}{ BOD $(\mathrm{mg} / \mathrm{L})$} & \multicolumn{2}{l}{ COD $(\mathrm{mg} / \mathrm{L})$} & \multicolumn{2}{l}{ TDS(mg/L) } \\
\cline { 2 - 11 } & Dry & Wet & Dry & Wet & Dry & Wet & Dry & Wet & Wet & Dry \\
& season & season & season & season & season & Season & season & season & season & season \\
\hline $\mathrm{SS}_{1}$ & 3.24 & 4.16 & 304.25 & 220.61 & 3.54 & 27.53 & 91.45 & 98.23 & 521.17 & 456.27 \\
& \pm 0.09 & \pm 0.01 & \pm 98.61 & \pm 74.93 & \pm 0.07 & \pm 12.31 & \pm 4.28 & \pm 1.52 & \pm 126.71 & \pm 145.31 \\
$\mathrm{SS}_{2}$ & 1.36 & 2.54 & 361.31 & 318.83 & 4.57 & 20.15 & 95.22 & 113.32 & 500.76 & 506.15 \\
& \pm 0.02 & \pm 0.04 & \pm 121.07 & \pm 67.42 & \pm 0.04 & \pm 0.08 & \pm 6.13 & \pm 7.92 & \pm 47.6 & \pm 83.65 \\
$\mathrm{SS}_{3}$ & 3.17 & 3.84 & 400.53 & 188.72 & 5.5 & 24.32 & 119.13 & 121.43 & 507.54 & 543.63 \\
& \pm 0.01 & \pm 0.06 & \pm 119.64 & \pm 93.47 & \pm 0.02 & \pm 0.06 & \pm 4.78 & \pm 15.74 & \pm 112.32 & \pm 132.17 \\
$\mathrm{SS}_{4}$ & 4.25 & 4.61 & 293.45 & 275.97 & 3.52 & 21.72 & 119.74 & 124.17 & 463.32 & 633.33 \\
& \pm 0.05 & \pm 0.09 & \pm 89.75 & \pm 54.61 & \pm 0.05 & \pm 4.03 & \pm 10.22 & \pm 31.07 & \pm 33.54 & \pm 321.21 \\
$\mathrm{SS}_{5}$ & 1.43 & 1.67 & 453.67 & 193.84 & 3.7 & 20.25 & 123.82 & 127.32 & 565.45 & 598.51 \\
& \pm 0.04 & \pm 0.03 & \pm 113.12 & \pm 132.32 & \pm 0.01 & \pm 6.46 & \pm 5.79 & \pm 9.32 & \pm 120.91 & \pm 151.34 \\
$\mathrm{SS}_{6}$ & 2.28 & 2.39 & 320.35 & 407.75 & 4.2 & 23.45 & 125.54 & 129.33 & 509.28 & 529.65 \\
& \pm 0.08 & \pm 0.07 & \pm 154.62 & \pm 77.87 & \pm 1.95 & \pm 11.05 & \pm 7.12 & \pm 10.23 & \pm 110.11 & \pm 119.04 \\
\hline
\end{tabular}

DO

The studied sites around flower farm and nearby watershed area show, low DO values in the dry season as compared to the wet season. The minimum dissolved oxygen (DO) was $1.36 \mathrm{mg} / \mathrm{L}$ during dry season whereas it was $1.67 \pm 0.03 \mathrm{mg} / \mathrm{L}$ in rainy season, which was below standard WHO.

\section{Total hardness}

The effect of dissolved minerals can be described by Total hardness Total (mostly $\mathrm{Ca}$ and $\mathrm{Mg}$ ), it can also describe the suitability of water for different purpose recognized to the presence of bicarbonates, sulfates, chloride and nitrates of calcium and magnesium. Water with hardness in the range $0-60 \mathrm{mg} / \mathrm{L}, 61-120 \mathrm{mg} / \mathrm{L}, 121-180 \mathrm{mg} / \mathrm{L}$ and $>180 \mathrm{mg} / \mathrm{L}$ are regarded as soft, moderately hard, hard and very hard, respectively. Surface water from the studied area recorded varying levels of total hardness between $293.45 \pm 89.75$ to $453.67 \pm 113.12 \mathrm{mg} / \mathrm{L}$ during dry season whereas it varied from $188.72 \pm 93.47$ to $407.75 \pm 77.87 \mathrm{mg} / \mathrm{L}$ in the wet season. Almost all the results show in the hard and very hard water range. The WHO report $(2004 \mathrm{a})$ recommends $<500 \mathrm{mgCaCO} / \mathrm{L}$ as the guideline value for surface water. In the studied area, generally be described as safe.

\section{BOD}

BOD determination is still the best available single test for assessing organic Pollution. The values of BOD at the studied sites ranged between $3.52 \pm 0.05$ to $4.20 \pm 1.95 \mathrm{mg} / \mathrm{L}$ during the dry season and $20.15 \pm 0.08$ to $27.53 \pm$ $12.31 \mathrm{mg} / \mathrm{L}$ during the wet season (Table 3-5). The maximum amount of BOD in water sample was measured during the wet season at the sampling site, $\mathrm{SS}_{1}(27.53 \pm 12.31 \mathrm{mg} / \mathrm{L})$. The average concentrations of BOD in the studied area was $4.17 \pm 0.02 \mathrm{mg} / \mathrm{L}$ in the dry season and that of the wet season were $22.90 \pm 4.12 \mathrm{mg} / \mathrm{L}$.BOD values in sampling sites $\mathrm{SS}_{1}(27.53 \pm 12.31), \mathrm{SS}_{3}(24.32 \pm 0.06), \mathrm{SS}_{4}(21.72 \pm 4.03)$ and $\mathrm{SS}_{6}(23.45 \pm 11.05 \mathrm{mg} / \mathrm{L})$ during wet season respectively were found to be above WHO desirable limit of $20 \mathrm{mg} / \mathrm{L}$ for irrigation, raw public water supply and aquatic life. However, BOD values in sampling sites $\mathrm{SS}_{2}(20.15 \pm 0.08 \mathrm{mg} / \mathrm{L})$ and $\mathrm{SS}_{5}(20.25 \pm$ $6.46 \mathrm{mg} / \mathrm{L}$ ) was found to be within the range of the guideline values. The results recorded during dry season were below WHO desirable limit of $5 \mathrm{mg} / \mathrm{L}$ for drinking use.

COD

The values of COD at the study sites was ranged between $91.45 \pm 4.28$ (control) to $125.54 \pm 7.12 \mathrm{mg} / \mathrm{L}$ (SS6) in dry season and $98.23 \pm 1.52$ (control) to $129.33 \pm 10.23 \mathrm{mg} / \mathrm{L}$ (SS6) during wet season (Table 3-5) which was found within the range of the guideline value of $\leq 150 \mathrm{mg} / \mathrm{L}$ recommended by EPA/WHO for fisheries and aquatic 
life.

\section{Nitrates}

From the Table 3-6 above surface water concentrations from the study area during dry season ranged from $2.55 \pm$ 1.44 to $6.27 \pm 3.38 \mathrm{mg} / \mathrm{L}$, whereas that of wet season varied from $3.45 \pm 1.76$ to $7.17 \pm 2.71 \mathrm{mg} / \mathrm{L}$. There highest concentration of nitrate has been observed in sampling sites $\mathrm{SS}_{2}(6.82 \pm 4.11 \mathrm{mg} / \mathrm{L}), \mathrm{SS}_{3}(5.44 \pm 3.01 \mathrm{mg} / \mathrm{L})$ and $\mathrm{SS}_{5}(7.17 \pm 2.71 \mathrm{mg} / \mathrm{L})$ respectively during wet season due to evaporation, percolating $\mathrm{NO}_{3}{ }^{-}$from sources such as decaying plant and animal materials, agricultural fertilizers and domestic sewage indicated that intensive use of fertilizer for flowers and crops were responsible for nitrate accumulation in surface waters. The minimum amount of nitrate in the water samples of the studied area was recorded during the dry season at $\mathrm{SS}_{1}(2.55 \pm 1.44 \mathrm{mg} / \mathrm{L}), \mathrm{SS}_{4}$ $(3.16 \pm 1.69 \mathrm{mg} / \mathrm{L})$ and $\mathrm{SS}_{6}(3.12 \pm 1.87 \mathrm{mg} / \mathrm{L})$ respectively as compared with the wet season. According to WHO water quality guideline limit of $10 \mathrm{mg} / \mathrm{L}$, the water in the studied area would be safe from polluting the existing water bodies in terms of nitrate.

\section{Phosphates}

The phosphate concentrations as $\mathrm{PO}_{4}{ }^{3-}$ measured at six sampling sites over two sampling seasons were generally highest during the wet season, with an average of $3.04 \pm 0.51 \mathrm{mg} / \mathrm{L}$ and that of dry season were $2.22 \pm 0.65 \mathrm{mg} / \mathrm{L}$ (Table 3-6). The average $\mathrm{PO}_{4}{ }^{3-}$ concentrations in both seasons were higher than the acceptable limit set by WHO prescribed limit of $0.1 \mathrm{mg} / \mathrm{L}$ for drinking water.

Table 3-6 Microbiological characteristics of ground and Surface water

\begin{tabular}{|c|c|c|c|c|}
\hline \multirow{2}{*}{ Sampling sites } & \multicolumn{2}{|c|}{$\begin{array}{l}\text { Ground water Total Coli form } \\
\text { (MPN/100ml) }\end{array}$} & \multicolumn{2}{|c|}{$\begin{array}{l}\text { Surface water Total Coli form } \\
\text { (MPN/100ml) }\end{array}$} \\
\hline & Dry season & Wet season & Dry season & Wet season \\
\hline $\mathrm{SS}_{1}$ & $4.26 \pm 0.04$ & $5.72 \pm 0.52$ & $19.75 \pm 1.12$ & $24.35 \pm 1.87$ \\
\hline $\mathrm{SS}_{2}$ & $4.59 \pm 0.02$ & $6.00 \pm 0.07$ & $9.93 \pm 1.06$ & $13.21 \pm 1.64$ \\
\hline $\mathrm{SS}_{3}$ & $4.10 \pm 0.01$ & $5.29 \pm 0.03$ & $14.25 \pm 2.07$ & $15.45 \pm 2.32$ \\
\hline $\mathrm{SS}_{4}$ & $4.42 \pm 0.06$ & $4.42 \pm 0.08$ & $10.57 \pm 1.97$ & $16.76 \pm 2.04$ \\
\hline $\mathrm{SS}_{5}$ & $4.84 \pm 0.09$ & $5.62 \pm 0.06$ & $11.65 \pm 1.63$ & $12.33 \pm 1.50$ \\
\hline $\mathrm{SS}_{6}$ & $4.95 \pm 0.05$ & $5.17 \pm 0.02$ & $20.81 \pm 3.06$ & $19.51 \pm 2.85$ \\
\hline
\end{tabular}

The results of bacteriological analysis of boreholes in Meshenti to Zegie showed contamination with total coliform during dry as well as wet season for both ground and surface sources. The total coli form for the dry season ranged between $4.10 \pm 0.01$-to $4.95 \pm 0.05 \mathrm{MPN} / 100 \mathrm{ml}$ and that of the rainy season was ranged between $4.42 \pm 0.08$-to $6.00 \pm 0.07 \mathrm{MPN} / 100 \mathrm{ml}$. As it can be seen in table 3-7, the bacterial colony counts were all above the WHO guideline limit of zero (0) MPN/100ml for drinking purposes.

\section{CONCLUSIONS}

Based on the data obtained from flower farm from Meshenti to Zegie Bikolo river watershed on water quality, temperature, $\mathrm{pH}, \mathrm{DO}$ and BOD were within recommended limits at each sampling point during dry, wet seasons, while turbidity, TDS, nitrate, phosphate and total coliform exceeded recommended values at particular points in groundwater samples as well as in surface water. All bacteriological parameters analyzed were above guideline limit for drinking water. Results of one-way analysis of variance performed on the data related to $\mathrm{pH}$, turbidity, TDS, DO, COD, and BOD suggested that all the measured parameters except temperature varied significantly among the sites (one-way ANOVA; $p<0.05$ ). There were significant spatial and temporal variations (ANOVA; $p$ $<0.05)$ in the concentration of nitrates and phosphates in ground and surface water, with the wet season having highest levels in all sampling sites.

The spatial water quality analysis of individual parameters showed that almost all of them have acceptable ranges except for nutrients and total coliform concentrations. Highest concentration of phosphates was recorded in sampling site $\mathrm{SS}_{6}$ followed by $\mathrm{SS}_{5}$ during the rainy season while in the dry season the highest level was in site $\mathrm{SS}_{4}$. The concentration of $\mathrm{NO}_{3}{ }^{-}$and $\mathrm{PO}_{4}{ }^{3-}$ in all sampling sites were also beyond the $\mathrm{FAO}$ and WHO guideline values for maintenance of fisheries, aquatic life, and domestic use.

Generally, the deterioration in the quality of water could be accounted to rapid urban-industrialization activities, huge investment in horticulture production, increase in population with change of lifestyle, excess use of chemical fertilizers, pesticides in soil to meet the increasing demand in the market, destroyed the quality of ecologically rich watershed area.

\section{REFERENCES}

1. Maxted, N. and S. Kell, CWR in crop improvement: to what extent are they used? Crop wild relative, 2009: p. 7.

2. Lal, R., Residue management, conservation tillage and soil restoration for mitigating greenhouse effect by CO2-enrichment. Soil and Tillage Research, 1997. 43(1-2): p. 81-107.

3. Mañosa, S., R. Mateo, and R. Guitart, A review of the effects of agricultural and industrial contamination on 
the Ebro delta biota and wildlife. Environmental Monitoring and Assessment, 2001. 71(2): p. 187-205.

4. Ayers, R. and D. Westcot, Water quality for agriculture. Irrigation and Drainage Paper No. 29. Food and Agriculture Organization of the United Nations: Rome, 1985.

5. Godfray, H.C.J., et al., Food security: the challenge of feeding 9 billion people. science, 2010. 327(5967): p. 812-818.

6. Arbuckle, K.E. and J.A. Downing, The influence of watershed land use on lake N: P in a predominantly agricultural landscape. Limnology and Oceanography, 2001. 46(4): p. 970-975.

7. Stålnacke, P., et al., Trends in nutrient concentrations in Latvian rivers and the response to the dramatic change in agriculture. Journal of Hydrology, 2003. 283(1-4): p. 184-205.

8. Hemond, H., EJ Fechner-Levy. Chemical fate and transport in the environment, 2000.

9. Gilvear, D., K. Heal, and A. Stephen, Hydrology and the ecological quality of Scottish river ecosystems. Science of the total environment, 2002. 294(1-3): p. 131-159.

10. Hayashi, M., Temperature-electrical conductivity relation of water for environmental monitoring and geophysical data inversion. Environmental monitoring and assessment, 2004. 96(1-3): p. 119-128.

11. Kimura, K., Reference voltage circuit compensated for temprature non-linearity, 2009, Google Patents. 